\title{
CONFLITOS: ANÁLISE DA LINGUAGEM TEATRAL A PARTIR DA TENSÃO ESTABELECIDA ENTRE O PÓS-DRAMÁTICO E O DRAMÁTICO
}

\author{
CONFLICTS: ANALYSIS OF THEATRICAL LANGUAGE FROM THE \\ TENSION USED BETWEEN POST-DRAMATIC AND DRAMATIC
}

\author{
Paulo Vieira ${ }^{1}$
}

Desde quando eu comecei a fazer teatro, em meados da década de setenta, falava-se que o teatro estava em crise. Nós vivíamos o auge de uma ditadura, uma das muitas que infernizou a vida nacional desde o primeiro golpe militar, a proclamação da república, em 1889. Por sinal, naquela época já agora longínqua, o teatro brasileiro também estava em crise, na qual o teatro "sério" começava a perder espaço no gosto do público para as revistas importadas da França. Mas a quarenta anos atrás o teatro ainda não havia saído da crise. Claro, a crise mudara. Não era mais o embate entre o teatro "sério" e a revista, entre a reflexão e a pândega, mas entre o teatro "engajado" e o teatro "agressivo", os novos nomes para a reflexão e a pândega.

Estamos agora no ano de 2020 e algumas coisas não mudaram desde ao menos o ano de 1889, entre elas a ameaça de uma outra ditadura militar e a crise no teatro. E claro, a crise contemporânea não é mais entre o teatro "sério" e a revista, ou entre o teatro "engajado" e o "agressivo", mas entre o teatro dramático e o pós-dramático, de certa maneira entre a reflexão e a pândega.

Em outras palavras, a crise do teatro é sobretudo a crise de sua própria linguagem. A crise entre a "tradição" e as "vanguardas".

Durante a década de setenta, quando a ditadura censurava previamente as artes, foi quando surgiu o teatro agressivo que chamou a atenção de críticos na dimensão do Anatol Rosenfeld, que se dedicou a analisar o estranho fenômeno. O teatro agressivo se dizia de vanguarda, pois comungava com as ideias das vanguardas históricas que pretendiam romper com uma narrativa que tem em Aristóteles o seu primeiro grande crítico. O nome de Aristóteles tornara-se adjetivo de algo a ser superado pela contemporaneidade, o aristotelismo. E o que é isto, afinal, senão a estrutura da linguagem narrativa do teatro, ou, por outra, da dramaturgia? Em termos gerais, esta linguagem se caracteriza por um contar história que tenha começo, meio e fim conduzidos por ação, conflito e personagens. E o que fazia o teatro agressivo dos anos setenta, além de romper com estes princípios estruturais da linguagem teatral? agredia ao público, daí a razão do seu nome. Gente na dimensão de um Paulo Pontes, na contramão dessa vanguarda, dizia que era preciso fazer teatro para o público, pelo simples motivo de que o teatro precisa do público e mais do que nunca o teatro brasileiro precisava de autores brasileiros que falassem de problemas brasileiros para o público brasileiro, e que, obviamente, o público agredido não retornaria à plateia. Nesse esforço para criar cumplicidade entre o palco e a plateia, Paulo Pontes escreveu Gota d'Água, seguramente uma das grandes obras do teatro não apenas brasileiro, mas do grande teatro do mundo. Ironicamente, uma peça que contém todos os elementos do "aristotelismo", como também um tema grego abrasileirado e que conduziu multidões para a plateia.

Agora, quando outra vez a obscuridade política paira sobre a vida nacional, a crise do teatro se dá entre o dramático "aristotélico" e o "pós-dramático", que tem no crítico alemão Hans-Thies Lehmann o seu grande pensador. Talvez a palavra "crise" não seja esteticamente adequada para o contexto do público, porquanto se antes o público era parte importante e ativa da discussão teatral, hoje o teatro se tornou tão desimportante que a sua discussão acontece

\footnotetext{
${ }^{1}$ Universidade Federal da Paraíba - UFPB.
} 
muito por um viés acadêmico, portanto para poucos, do que por uma direção profissional, que visa ao grande público, ao público de massa, e não aos iniciados encastelados em cátedras.

O teatro, sobretudo o pós-dramático no Brasil, deixou de ser um ponto de vista, uma realização ou provocação estética, e se tornou a ilustração de uma palestra a ser dada pelos atores ao final do espetáculo, quando finalmente o público será esclarecido sobre o que viu ou vivenciou durante a performance apresentada. Não é incomum o público ser convidado pelos atores, ao fim do espetáculo, a permanecer no teatro para debater o que lhe foi apresentado.

A grande questão de fundo, do meu ponto de vista, sobre o teatro contemporâneo de tendência aparentemente majoritária ao pós-dramático, é quanto ao desaparecimento do teatro dramático. O que eu me pergunto é se isto não seria o desaparecimento do próprio teatro enquanto arte, enquanto linguagem? Em um artigo publicado em Revista Brasileira de Estudos da Presença ${ }^{2}$, Lehmann, discutindo o conceito de teatro, agora não mais em relação ao dramático (pois este "aponta na direção de algum dado antropológico eterno, porém prestes a perder terreno") e sim entre a tensão do pós-dramático com a performance, afirma não estar convencido (ou não estava ainda) de que faça sentido desistir do termo "teatro", submetendo toda a prática teatral ao termo "performance".

Este não é apenas o reino dos conceitos, mas segue uma direção para muito além, pois se trata na verdade de uma prática que tem no espetáculo o seu fim. Aliás, no campo do pósdramático até a palavra "espetáculo" não faz muito sentido, por mais que signifique algo relacionado a apresentação pública, o seu espectro semântico está profundamente relacionado a representação, portanto ao dramático, uma vez que representar não é da natureza do pósdramático. Muito menos da performance, que atravessa e engloba o conceito e a prática do pósdramático. Em sua defesa para a permanência do uso do termo "teatro", cada vez mais suprimido pelo pós-dramático transcendido pela performance, Lehmann afirma que as Teorias da Performance e do Teatro operam em bases comuns.

Em minha prática e em minha visão, o teatro como um todo (por extensão o pós-dramático e a performance) está em profunda desconexão com a sociedade contemporânea, atravessando uma entropia de linguagem capaz de o conduzir ao não teatro. O que não deixa de ser curioso, porque, mais do que nunca, vivemos em uma sociedade global preconizada por Marshall McLuhan ainda em 1962, em A Galáxia de Gutemberg, livro no qual o sociólogo canadense aponta para o fenômeno da contemporaneidade: as mídias de massa interligando o mundo, estreitando relações econômicas, políticas e sociais, uma sociedade para a qual o meio é a mensagem. Enfim, a era da comunicação. Da comunicação de massa, bem entendido. Agora mais do que nunca, com a internet no bolso de cada um a toda hora, a todo instante, em qualquer lugar do planeta. A grande contradição é que o teatro deixa de comunicar na era da comunicação. E por que o faz? Do meu ponto de vista, justamente porque abdicou de sua linguagem. Embora no campo teórico tenha ocorrido com o teatro não uma perda, mas uma atualização de linguagem para estar de acordo com a sensibilidade contemporânea, a prova do que está posto não está nos livros das estantes, mas nas plateias dos teatros.

Há muitos modos de pensar e de fazer o teatro. Talvez não haja um melhor do que o outro, mas eu creio que a sua prática exige reflexão para além do campo acadêmico, um pensamento que deve conduzir um fazer para muito longe dos campi, lugar onde o pensar acontece no plano do meramente teórico. Talvez seja preciso pensar o teatro não apenas como objeto de estudo ou de conhecimento, mas como ação profissional. E neste sentido o teatro agoniza, morre lenta e dolorosamente.

\footnotetext{
${ }^{2}$ Hans-Thies Lehmann - Teatro Pós-dramático, doze anos depois Rev. Bras. Estud. Presença, Porto Alegre, v. 3, n. 3, p. 859-878, set./dez. 2013. Disponível em: <http://www.seer.ufrgs.br/presenca>. Acesso em: 19 de novembro de 2019.
} 
Quando na década de setenta Paulo Pontes lutava para que o autor brasileiro estivesse no palco brasileiro, contando uma história brasileira, o que ele queria na verdade era conectar o teatro com o público, pela simples razão de que sem público não há teatro. A obviedade do que está posto dispensa a etimologia da palavra "teatro". É verdade que uma das características da contemporaneidade é a fragmentação da linguagem. Quando na década de setenta se falava que o teatro estava em crise, a causa apontada era de que a televisão dividia ou afastava o público da plateia. Mas antes da televisão, o que houve? No tempo do Bruxo do Cosme Velho a causa seria mesmo o Teatro de Revista? (en passant: o Teatro de Revista com a sua narrativa fragmentada em quadros bem que poderia ser tomado como uma forma arcaica do pósdramático). Esta é uma questão ainda aberta na historiografia do teatro brasileiro. Mas talvez não. E hoje, qual seria a causa? A TV, o cinema, os computadores, os tablets, os celulares nas mãos das pessoas? Do meu ponto de vista, o pós-dramático significa não a construção de uma outra ou nova linguagem, mas a fragmentação da velha e boa estrutura narrativa dramática, que nos proporcionou tanto as obras de Sófocles quanto as de Shakespeare, assim como Nelson Rodrigues, Molière, Ariano Suassuna, e por aí vai, constituindo-se através dos séculos numa sólida herança do teatro voltado para o humano, em todos os aspectos, e que obviamente não nos esgotou enquanto objetos temáticos, porque é do meramente humano de que trata a arte.

E este é o grande xis da questão: o humano. Então não há como evitar Aristóteles, que, por sinal não inventou nem o teatro nem a estrutura da linguagem. Quando alguém fala "teatro aristotélico", certo, eu compreendo, mas entendo que o termo está posto fora do lugar. Mas não há como esquecer as lições do mestre. E o que diz o estagirita em sua Poética? Entre outras coisas, a simples obviedade de que nós gostamos de ouvir histórias. É da nossa natureza. Desde pequeno nós gostamos de histórias. Nós nos divertimos ouvindo - e assistindo - histórias. Aprendemos ouvindo - e lendo - histórias. Nas histórias estão guardadas as nossas memórias pessoais e coletivas. A Bíblia, As Mil e Uma Noites, O Alcorão, Os Vedas, livros sagrados e consagrados pela tradição, que moldaram culturas tanto no oriente quanto no ocidente são livros que nos contam histórias. A vida dos Orixás e do panteão olímpico são histórias. A nossa própria vida é a nossa história. As novelas da TV nos contam histórias. Dramáticas, trágicas, cômicas, não importa, são histórias, gostamos de histórias, de terror, de ficção científica, contos de carochinha, desenhos animados, e até mesmo as já agora esquecidas fotonovelas, radionovelas, são histórias, nossa vida do berço ao túmulo é um contínuo contar de histórias. Qual o problema então com o pós-dramático? Em nome de romper com uma tradição abdica de contar uma história. É até possível que a fragmentação seja o desenvolvimento de uma outra linguagem, mas é também um recurso simples, enquanto linguagem, e que não contempla a narrativa de uma história que aconteça em um espaço e tempo, e por esse motivo não envolve o espectador em uma teia ficcional e abdica de estabelecer conexão que atravesse o modo cerebral. O pós-dramático, enquanto linguagem, é algo semelhante aos emojis presentes nos sistemas de comunicação eletrônicos, algo que comunica, sim, mas não expressa nem sentimentos nem vontades ou desejos, não fala de você, não revela a pessoa por trás da figura, não permite que se veja, sinta ou perceba o humano se comunicando com outro humano, mas apenas um sinal eletrônico se conectando a outro sinal eletrônico. Diferentemente das velhas cartas que recebíamos pelos correios, que diziam da vida, contavam história, derramavam-se em sentimentos que podiam, posteriormente, ser editadas para deleite do público, que poderia, finalmente, conhecer a intimidade de alguém que viveu uma história (de amor ilusório como as Cartas Portuguesas da Soror Mariana Alcoforado, no século XVII; ou as desesperadas cartas de Van Gogh ao irmão Theo, no século XIX; as cartas de Anayde Beiriz em 1928; ou mesmo, a mais recente das cartas transformadas em livro, a correspondência de dois escritores contemporâneos, trocadas entre 2008 e 2011, Paul Auster e J. M. Coetzee, Here and Now). 
Enfim, emoji é linguagem, mas não comunica o humano em toda a nossa subjetividade. De modo semelhante acontece com o pós-dramático. E neste caso, associado ou transitado para a performance, abdicando o discurso semântico, apoia-se na estética da fisicalidade, fazendo uma aproximação com a dança mas não se constituindo dança nem teatro, mas em "performance", ou, para usar um termo que me parece mais adequado por ser acadêmico, uma "antropologia pessoal", pretendendo muitas vezes se tornar um meio para despertar interesses social ou político, quase sempre me dá a sensação de que se trata antes de catarse individual do que abrangência coletiva. Porém, como afirma o próprio Lehmann no artigo supracitado, a linguagem do corpo não é tudo.

Não bastasse, pela falta mesma de um texto organizado segundo uma lógica narrativa, estrutural, de linguagem, uma apresentação (não confundir com espetáculo) dessa natureza aparenta trazer consigo um sem número de ideias, mas ao fim quase não resiste a um confronto, justamente porque aquilo que aparenta ser mais é menos, aquilo que parece revestido de ideias se revela sem. Sem tantas ou sem nada.

Mas há um princípio, ou uma ideia se você assim o quiser, norteador do teatro pós-dramático: a dramaturgia do espectador. Abdicando do autor, do dramaturgo responsável por criar a situação dramática, o teatro pós-dramático necessariamente, por vontade ou por não haver outra solução, abre espaços vazios entre os quadros que precisam, ou devem, ou deveriam ser preenchidos pelo espectador. Considerando que esses lapsos sejam intencionais, caberia ao espectador completar as lacunas como um jogo, um quebra-cabeças, um chamamento para a razão, ao contrário da velha ordem na qual o teatro se comunica antes pela sensibilidade e emoção. E graças ao artifício da incompletude dramatúrgica abre-se a ruptura com a representação dramática.

Tudo isso que pertence ao campo teórico não se restringe aos artigos e ensaios acadêmicos, mas orienta uma prática teatral que tem se tornado constante e com resultados cada vez mais visíveis. Eu penso no teatro como profissão e não como missão. E nesse aspecto, o teatro tem notoriamente perdido público aqui e também alhures. A velha crise de que tanto se fala. Claro que a perda de público não é um fator isolado, mas está contido em um contexto social e econômico muito mais abrangente e que não depende das gentes de teatro e tampouco das teorias que possamos desenvolver. Alguns fatores são determinantes em nosso país, como, por exemplo, a violência e o crescimento das cidades em função do aumento populacional. Tenho observado que os teatros, de maneira geral, foram construídos nos centros das cidades, onde as pessoas moravam, agora transformados quase que completamente em centros comerciais. Por essa razão, lugar que costuma estar ermo durante as noites. Quase sempre esses são lugares melancólicos quando a noite vem, e não raro, temidos. Mas o que isso tem a ver com o pós-dramático de que se fala? Tudo e nada, ao mesmo tempo. Nada, se pensarmos que o pós-dramático se dá no interior da feitura teatral. E tudo, se pensarmos que o teatro depende do público, é feito para alguém, destinado a alguém, visando os espectadores, que, nas palavras do próprio Lehmann "não encontram nenhum drama ou identificação com o personagem fictício, mas tem de lidar, ao invés disso, com a presença real dos atores. Esse tipo de teatro permite que os espectadores experimentem uma profunda relação com o ator/performer - embora muitos saiam do teatro decepcionados porque o espetáculo esperado lhes foi negado"3. Não bastassem as condições urbanas dos teatros, que por si só obrigam aos espectadores a um deslocamento um tanto temeroso, ao fim o que o público pode receber da cena é decepção.

Sim, há o fator político. Mas o teatro não é exatamente tribuna. É diversão. A mesma diversão que nos faz ir aos cinemas, que, por sinal, abandonaram os centros das cidades e estão dentro dos shoppings centers, lugares onde as pessoas vão sem receio de violência. E por falar

\footnotetext{
${ }^{3}$ Op. cit.
} 
em cinema, ao menos até onde alcança o meu conhecimento, apenas uma vez, na década de sessenta, o cinema pôs em questão a sua linguagem, durante a Nouvelle Vague francesa. E o que houve naquele movimento foi a ruptura de ação, filmes cujos roteiros não tinham progressão tempo-espaço, com começo, meio e fim desenvolvidos para contar uma história, abrindo mão da lógica dramatúrgica. O cinema, mesmo o cinema francês, logo abandonou essa experiência (e ao menos em nosso país, abandonou também os centros das cidades e inclusive os cinemas de bairros) e se manteve fiel a uma dramaturgia aprendida com o teatro. Ao contrário deste, que não cessa de pôr a sua linguagem em conflito, as revoluções no cinema acontecem muito mais nas linhas de produção das indústrias de equipamentos do que nos sets ou nos roteiros. Resultado visível é que as pessoas vão aos cinemas muito mais do que aos teatros. Dos cinemas as pessoas em geral não saem decepcionadas, mas quase sempre motivadas a discutir e a conversar sobre os filmes. Não é a mesma coisa na forma, mas não há como esquecer que de fundo as coisas se equivalem como a luta do Paulo Pontes contra o teatro agressivo. Espectador frustrado, agredido ou decepcionado, há de ser um espectador a menos na plateia. E o menos, claro isto, não é mais. Então, o teatro abriu mão de ser uma arte do povo, uma arte de público, para se tornar a arte de acadêmicos, discutido apenas nas academias, comprometendo com isso a prática profissional, que desde os fins dos anos setenta com a criação dos cursos de teatro nas universidades abandonara os palcos em função das cátedras.

As experiências sensoriais dos atores nas performances podem e devem ser muito interessantes para si mesmos, mas não para o público em geral. Tenho dito, meio por graça, meio por verdade, que não se pode mais ir ao teatro sem o livro do Lehmann debaixo do braço, sob o risco de não se saber exatamente o que se está assistindo. O teatro dramático foi atacado durante o último século de todas as formas possíveis. Inicialmente pelas vanguardas históricas, que abriram a discussão sobre a criação de uma nova linguagem, mais adequada a sensibilidade do século da ciência. Para muitos, a estrutura dramatúrgica "aristotélica" não correspondia às necessidades de um novo tempo. Era preciso reinventar o teatro. Mas não se rompe uma linguagem sem criar uma crise no sistema comunicacional desta linguagem. O que sustenta e mantém a permanência de uma linguagem é a qualidade da obra que dela resulta. Afora a provocação do gosto estético, poucas obras, até onde eu sei, conseguiram resistir à prova do tempo. Entre elas, algumas de Beckett, incluindo aquela que já é um clássico da contemporaneidade, Esperando Godot. Aqui sim, os elementos "aristotélicos" da linguagem foram subvertidos de modo a criar uma obra que se constitui em si a sua própria linguagem, a começar pelo título, pois em teatro (fundamento de linguagem) não se espera. Teatro é ação. É o acontecer alguma coisa. Mas a coisa acontecida, para se constituir em ação teatral, deve partir de um ponto a outro, modificando-se no tempo-espaço através dos conflitos entre personagens. Essa estrutura simples foi a que gerou as obras de referências mundiais dos mestres da dramaturgia. Mas o simples, na verdade, é aparente, pois a grande complexidade desta estrutura, o, por assim dizer, DNA da dramaturgia precisou de um tempo algo próximo a quarenta anos, entre o início das vanguardas e o aparecimento da obra modelar de Beckett, para, finalmente, haver a composição de um texto que rompendo com a estrutura de ação e conflito tenha resultado em singular qualidade dramatúrgica e que se tornou modelo e referência para a posteridade. Em Esperando Godot, dramaturgicamente falando, não há ação nem conflito. Entretanto, ao romper com uma estrutura de linguagem faz-se necessário que outro elemento ocupe o lugar daquilo que foi subtraído, e neste caso, ação e conflito foram substituídos por ritmo, sutilmente colocado na extensão das falas das personagens. Falas curtas na maior parte da obra, indicando predominantemente um ritmo Allegro. Com o passar do tempo, a dramaturgia de Beckett foi se tornando cada vez mais minimalista, onomatopéica até, saudada 
pela crítica como uma nova fronteira da linguagem teatral quando, para além da paixão, bem que pode ser vista como o esgotamento de um veio criativo.

Um dos grandes pensadores do século XX a investir contra o teatro "aristotélico" foi Bertolt Brecht. Entretanto, ao negar a teoria clássica ele próprio, de certa maneira, a parodia ao se referir ao épico, adaptando o conceito às suas pretensões, pois se em grego a etimologia da palavra é relativa a heróico, em termos brechtianos épico é relativo ao comentário paralelo que pode ser em forma de canção, ou de cartaz, ou de outra coisa que se deseje, de maneira que pare a ação e com ela a ilusão e a emoção, de maneira que o público não se esqueça que está dentro de um teatro, assistindo a um espetáculo de teatro, como se fosse possível a alguém se dirigir ao teatro e durante a cena imaginar que está em outro lugar que não seja o próprio teatro, que não está assistindo a uma obra de ficção. Sim, claro, o propósito do épico em Brecht é político e social, mas apesar de frágil enquanto argumentação e teoria, moldou o pensamento de toda uma geração da segunda metade do século XX, contribuindo enormemente para com o rompimento da ação teatral, abrindo caminho no final do século para os conceitos que aportam o pós-moderno. Brecht foi sobretudo um grande dramaturgo. Não tenho ciência para tanto, mas não me recordo de em algum lugar ter lido que grandes obras do Brecht como A Vida de Galileu ou Os Fuzis da Senhora Carrar são profundamente "aristotélicas"4.

$\mathrm{O}$ efeito de distanciamento proposto por Brecht acabou sendo apontado como uma forma de trazer a consciência ao palco, ao elucidar para o espectador as questões que as obras apontem, tornando assim o teatro um veículo de conhecimento e de conscientização dos problemas sociais, políticos, econômicos, relacionais, enfim, tudo o que pode e deve ser matéria de teatro. Ao fazer esta proposta e enveredar por esse caminho, Brecht elimina a tensão entre personagens e isto tem efeito sobre a técnica de escrita dramatúrgica, assim como vai se tornar modelo para um sem número de dramaturgos e diretores experimentarem outro modo de criar a obra teatral sem passar pelo veio apontado por Aristóteles em sua Poética. Do meu ponto de vista, a tensão entre personagens significa mais do que conflito, mas o embate de ideias e de princípios (sociais, políticos, econômicos, relacionais, etc.) que as personagens trazem para a cena, colocando-as em discussão não através de cortes sucessivos na ação, mas estabelecendo uma relação dialética, na qual as razões de ambos os lados (protagonista e antagonista) movimentam as ideias e as emoções que estão contidas nas ações e nos conflitos, gerando por isso mesmo uma dinâmica interna da cena, e este elemento resultante atinge o espectador ao nível da emoção, não purgando-a, eliminando-a, mas fazendo o espectador sentir e refletir enquanto é envolvido por uma história que contenha os elementos necessários e fundamentais da linguagem teatral. $\mathrm{E}$ tudo isso para o bem do espectador, razão última e primeira do teatro. E se é para o bem do espectador, há de ser também para o teatro enquanto linguagem artística, para o teatro enquanto ofício.

\section{Sobre o autor}

Paulo Vieira é Professor Titular no Departamento de Artes Cênicas da Universidade Federal da Paraíba (UFPb). Doutor em Artes pela Universidade de São Paulo (USP). Realizou o PósDoutorado no Théâtre Du Soleil, na França. Ator, Dramaturgo, Roteirista e Diretor de Teatro. E-mail: pvvieira@hotmail.com.

\footnotetext{
${ }^{4}$ Ambas editadas no mesmo volume: Brecht, Bertolt. Teatro Completo. v. 6 . Rio de Janeiro: Paz e Terra, 1991.
} 